\title{
TTR
}

Traduction, terminologie, re?daction

\section{Poetry, Science, and the Epistemological Debate}

\section{John Picchione}

Volume 12, numéro 1, 1er semestre 1999

Poésie, cognition, traduction I

Poetry, Cognition, Translation I

URI : https://id.erudit.org/iderudit/037351ar

DOI : https://doi.org/10.7202/037351ar

Aller au sommaire du numéro

\section{Éditeur(s)}

Association canadienne de traductologie

ISSN

0835-8443 (imprimé)

1708-2188 (numérique)

Découvrir la revue

Citer cet article

Picchione, J. (1999). Poetry, Science, and the Epistemological Debate. TTR, 12(1), 19-30. https://doi.org/10.7202/037351ar

\section{Résumé de l'article}

La poésie, la science et le débat épistémologique - Au cours des dernières décennies, nous avons assisté à une remise en question radicale des possibilités cognitives qui étaient traditionnellement associées à la littérature et à la science. Le présent article se veut un bref survol de ce débat et une critique de la déconstruction et du post-modernisme dans leur tentative de remettre en question certaines des revendications épistémologiques fondamentales. Par la suite, l'article aborde la spécificité de la cognition poétique et, se distinguant des conceptions imitatrices de la poésie, propose que la poiêsis entraîne une création particulière de la réalité, inaccessible avec d'autres outils. C'est le caractère unique de la matérialité du langage poétique qui contribue à la formation de la subjectivité et au développement de la réalité humaine et de la conscience.
Tous droits réservés @ C TTR: traduction, terminologie, rédaction — Les auteurs, 1999
Ce document est protégé par la loi sur le droit d'auteur. L’utilisation des services d'Érudit (y compris la reproduction) est assujettie à sa politique d'utilisation que vous pouvez consulter en ligne.

https://apropos.erudit.org/fr/usagers/politique-dutilisation/ 


\title{
Poetry, Science, and the Epistemological Debate
}

\author{
John Picchione
}

The last few decades have witnessed a radical questioning of the epistemological functions traditionally associated with science. In fact, the dominant trait of a number of intellectual groups is represented by their attempt to devaluate, on a theoretical level, the cognitive possibilities of any scientific inquiry. It should be stressed, however, that the attack on science launched particularly by the philosophy of post-structuralism and deconstruction already had an established legacy. Its general orientation can be easily traced back to Nietzsche's antifoundationalist philosophy and to Heidegger hermeneutics'. The works by Derrida, Lyotard, Foucault, Vattimo, Baudrillard and others, which can be classified under the broad label of post-modern thought, have essentially only pushed forward the assault on the citadel of science $^{2}$. In their substance, most of the strategies are not entirely new.

\footnotetext{
'Presenting a radical critique of any concept of truth, Nietzsche's works reduce science to a subjective construction (see in particular The Gay Science). For Heidegger's hermeneutics there is no understanding, including that associated with science, without prejudice.
}

${ }^{2}$ It is not possible to discuss here the specific position of each theorist; it will suffice to say that they all contribute to a questioning of scientific knowledge by advocating a sceptical and relativistic perspective which privileges the multiple, the heterogeneous, and the indeterminate. In this general philosophical trend, knowledge is either tied to shifting centres of power or becomes a fabrication of linguistic illusions ungrounded in any reality (the real can actually vanish, giving rise to a world of simulacra in which there are no certainties or facts of any sort). See Derrida, L'écriture et la différence; Lyotard, La condition postmoderne; Foucault, L'archéologie du savoir; 
(It should be noted that fundamental epistemological issues were raised within the scientific community as far back as the 1920s, specifically by Heisenberg's uncertainty principle and by the theories of subatomic physics in general ${ }^{3}$ ).

Nonetheless, the post-modernists have undoubtedly strengthened the view of science as a manipulation of reality as opposed to a cognitive activity. Objectivity and truth, historically regarded as irrefutable tenets of science and as its well-defined demarcations from the arts or from other human undertakings, have been fiercely targeted. In this perspective, scientific knowledge is no longer seen as being grounded in empirical investigations guided by logical, unbiased, and metahistorical observations. On the contrary, it is conceived as a result of temporal paradigms which are inevitably entangled in a web of cultural and epochal limitations. Accordingly, it is the theories engendered by our paradigms which create scientific facts and not vice-versa. That is to say, it is impossible to observe facts independent from the theories which produce them. Essentially, the claim is that a metatheory capable of indisputable verifications and validations does not exist. Science is an expression of ideology, heavily compromised by social and psychological factors, or by political

Baudrillard, Simulacres et simulation; Vattimo, La società trasparente. Here, for example, is a statement by Vattimo: "scientific rationality which for centuries has represented a guiding value for European culture is, ultimately, a myth, a shared belief on which the organization of this culture is based." (Vattimo, 1989, pp. 50-51)

${ }^{3}$ It should be added that thinkers working within the context of the philosophy and history of science had considerably undermined epistemological absolutes long before it became fashionable in literary circles. Popper's falsification theory (The Logic of Scientific Discovery) and Kuhn's relativism (The Structure of Scientific Revolutions) are, although rather distant in their conclusions, the most obvious examples. Kuhn's concept of scientific paradigms is a clear anticipation of the post-modernist notion of "metanarratives"; both deny any possible claim to universal truths and objectivity. Feyerabend's anarchist epistemology (Against Method) can also be placed within this theoretical orientation. His basic argument is that science projects as biased a world-view as any other discourse and consequently it does not possess a method to discover any truth - there are no epistemological claims that can never be violated. 
interests. Science too can be placed, at a superstructural level, not only within the ideological expressions of class and gender, but within the parameters of the institutions which regulate its research and projects.

The principal arguments against the validity of scientific claims can be summarised as follows :

1. there is no accessibility to raw reality inasmuch as it will always be mediated by pre-given linguistic and mental structures;

2. cognitive results are inseparable from the specific method adopted and from the dialectic subject-object; it is the observer who determines the way an object is perceived, thus making it impossible to provide knowledge of the object in itself;

3. there exists an epistemic impossibility to ground any proposition, scientific or otherwise; no verification of any truth claim can be considered authentic and legitimate;

4. science is not autonomous with respect to dominant ideologies and institutional structures; it is dependent on social legitimation and social power;

5. scientific knowledge - as for instance maintained by Kuhn - is erroneously believed to be cumulative; instead, it is regulated by transient paradigms which are inevitably displaced by new scientific revolutions;

6. science started out as a project aiming at uncovering the mythologies of the world and it has turned itself into a myth;

7. science, as any other discourse, is a language game with no foundation inasmuch as it cannot be grounded in any reality or knowledge.

Greatly influenced by the philosophy of the later Wittgenstein, this last postulate is embodied in particular by the works of Lyotard. According to the French philosopher, the historic conflict between scientific knowledge and narrative knowledge - that is knowledge derived from myths, legends and tales - is deceptive. Science too 
must adopt, as a language game, narrative language in order to provide legitimation of its own knowledge4.

It would be erroneous to conclude that the epistemological debate, which is here briefly outlined, is weighted in favour of the arts or of literature and poetry in particular. Basically, deconstructive and post-modern theories, with their claims of a language without referents, subvert all principles of knowledge and try to destroy the humanistic view of a subject guiding the process of signification. In fact, as language-centred theories, they announce the absence of the author in the act of writing and portray all forms of verbal communication as being trapped in a labyrinth of tropes with no access to reality. Science is in essence reduced to textualism, to a literary genre with no escape from the discursive (See Rorty, 1980, in particular p. 141). Guided by intralinguistic and intertextual views, these positions announce the catastrophe of human cognition inasmuch as they assume that the nature of language is fictitious, and verbal signs inevitably dissolve in a semantic vacuum which makes it impossible to attach a signifier to any signified.

Such claims represent a form of nihilistic philosophy and absolute scepticism which reveal the cyclical return of irrational thought. In the prison-house of language, they mistake epistemology with ontology and they are forced to negate in the most radical fashion the existence of a reality independent from our representations. Advocates of these principles are left stranded in a serious philosophical contradiction, in a sort of aporia of the sceptic : on the one hand, they negate the possibility of truth and, on the other, they affirm to know something, thus having knowledge of the truth. They declare their total disenchantment with so-called metaphysical or teleological thought, but they base their entire philosophical orientation on a metaphysical axiom - the claim that reality is unknowable.

These theories generated a number of false assumptions in literary circles, stirring up confusion and causing various damaging effects. Moved by the urge to jump on the band-wagon of the latest

\footnotetext{
+ Lyotard (La condition postmoderne) rejects any possibility of transcendence and reduces science to a language game which requires the same narrative knowledge that it discredits for its own legitimation.
} 
philosophical doctrines, many have concluded that everything is just rhetoric; scientific knowledge, truth, and evidence are myths; the linguistic code is a self-referential system of signs; there is no real outside of our representations, and the world is constituted by an infinite series of empty simulacra. This, in turn, has caused a devaluation of the connections between literature and reality, depoliticizing the literary activity and exposing it to a form of bourgeois liberalism - a babelic and narcissistic consumption of language games without an ethos and without the possibility to propose alternative world-views. In a human and natural world dominated by arbitrariness, discontinuity, randomness and chaos, it would seem that there is no room for any cognitive mapping either in the context of scientific inquiry or in the context of literary projects.

Few would oppose the position that absolute understanding of nature probably lies beyond the limits of our knowledge and that a value-free inquiry in the realm of the noumenon may be doomed to failure. Nevertheless, in defence of scientific undertakings, it is possible to maintain that - until proven otherwise - science shows, through its iterability of results, the ability to predict physical phenomena and to achieve knowledge by successive approximations. Science draws empiric maps which assist us to understand and master the physical world, making more familiar the space in which we are destined to live. Science constantly clears the world of mythologies and expands its frontiers but, at the same time, it is incapable of creating subjectivity, mental and emotive cartographies. This is the realm which, arguably, more than any other human activity, belongs to poetry.

The exploration of this perspective entails a number of questions which can be framed as follows : is it possible to speak of literary knowledge or poetic cognition in particular? What is its specificity? What are some of the fundamental constituents and processes intrinsic to poetic creation? Do they really differ from those adopted by ordinary language? Do they represent a deviation from the norm?

Giambattista Vico, a thinker who addressed some of these problems, answered that poetic knowledge pertains to the domain of the senses which he identifies with the primitive age of humanity. For 
the Italian philosopher, poetic cognition precedes knowledge derived by the intellect and it constitutes its foundation inasmuch as "Nihil est in intellectu quin prius fuerit in sensu" (Vico, 1968, p. 110). Rejecting both classical and Renaissance literary theories, Vico argues that poetic tropes are not simple ornaments or disguises of rational concepts. The tropological, as a manifestation of sapienza poetica, is the first expression of human culture and consciousness (indeed, the human world owes its formation to the tropological) from which all forms of abstract thought are derived. Poetry is the embodiment of the language of myth : the fantasy and the feelings of the primitive mind projected in the form of images capable of capturing human "universals". Vico writes :

All the first tropes are corollaries of [...] poetic logic. The most luminous and therefore the most necessary and frequent is metaphor [...] every metaphor so formed is a fable in brief $[\ldots]$ by a necessity of human nature, poetic style arose before prose style; just as, by the same necessity, the fables or imaginative universals, arose before the rational or philosophic universals, which were formed through the medium of prose speech. (Vico, 1968, p. 129, p. 154)

The association of poetry with a tool for getting to know the world through fantasy, imagination, and feelings has cut across many ages and poetic theories. Nevertheless, it was Romanticism that announced that the poetic experience represents a form of consciousness actually much higher than scientific knowledge. The great Italian Romantic poet, Giacomo Leopardi, set out to clarify that the function of poetry is not representational but creative. "To consider and define poetry as an art of imitation," he writes in his Zibaldone, "is a very false idea [...] The poet imagines: the imagination sees the world as it is not, it forges a world which is not [...] creator, inventor, not an imitator : this is the essential character of the poet." (Leopardi, 1983, pp. 1174-1175)

The issue of poetic cognition is in fact often distorted by the mimetic tradition - mimesis seen as the principle which constitutes the core of any poetic expression. Poetry, as well as literature and art in general, is perceived solely as a vehicle of representation, a medium aimed at depicting a pre-given reality and thus functioning as its 
mirror. It is considered an artistic attempt to capture external reality or to translate, in a special and more intense language, feelings and ideas experienced before the act of writing. For representational systems, reality and experience are conceived outside of language and precede signification, a tradition grounded in Platonic thought. The Greek philosopher envisages poetry as an imitation of the sensible - i.e. perceptible by the senses - universe and since the latter is itself an imitation of the world of Ideas, it follows that poetry is an imitation of an imitation, a copy of a copy, a shadow of a shadow, a lie which diverts the soul from the eternal and universal essence. Not surprisingly the poets are banished from the ideal Republic.

It can be argued that poetry, like all other forms of artistic expression, can never be completely disentangled from principles of mimesis since absolute autonomy or unequivocal self-referentiality are not only very disputable - no matter how alluring the intralinguistic theories of deconstruction may appear in some literary circles - but catastrophic at the same time. On the other hand, if the traditional canon of mimesis is maintained, poetry becomes a tautological form of knowledge inasmuch as it captures what is already there or knowable through another medium. A parallel issue arises if poetic cognition is compared to the discourses produced in a philosophical, political, or sociological context. To think of poetry as a reproduction, albeit in a different form, of these discourses would make it a redundant or, at best, an ancillary activity. The autonomy of poetry vis-à-vis philosophy is central to this problematic.

The opposition of the mimetic tradition by the principle of self-reflexivity constitutes another dead-end for poetry's cognitive possibilities. As a form of pure signs without referents, a narcissistic mirror of itself, poetry would inevitably cut itself off from any outside reality : empty, fictitious signs in love with themselves and without a world. Opposed to this view there is the claim that all artistic structures, including poetry, should invariably be seen as epistemological metaphors. All forms created through art are metaphoric equivalents of an "assimilated cultural persuasion" as Umberto Eco maintains (Eco, 1962 , p. 151). However, the fundamental issue here is whether the poetic world pre-exists the creative process or whether poetic language performs a specific role in the formation both of the self and of human realities in general. 
In order to explore some alternatives to representational theories, it is necessary to turn to a radically divergent tradition, one that is unquestionably epitomized by the avant-garde and experimental practices. Arguably, starting with Mallarmé, these practices moved away from a theory of reflection and advocated a conception of poetry as an activity centered around the materiality of language and the rupture of the linguistic norm. Poetry becomes a disruptive force that puts in motion new cognitive dimensions. As an exploration of the infinite potentialities of language, poetry champions the primacy of the signifier and pushes the linguistic code to limits that no other human activity can equal. In this approach, reality is not immediately accessible to consciousness. The latter is the result of the unavoidable mediation by the signifiers. Thus poetry becomes the great intermediary between language and reality - not in the sense that it reproduces it, but in the sense that it is able to bring to consciousness aspects of reality which were otherwise not immediately accessible.

As a transgressive energèia, poetry breaks the boundaries of our ordinary communication and in so doing broaches alternative models of knowing the world and interacting with it. In this case, it is the poetic language that produces centrifugal effects and not the other way around. Indisputably, poetry is an heteronomous activity inasmuch as it is the result of an encounter with extratextual realities. However, it is first and foremost the product of a dynamics put in motion by the internal movements of the poetic text. Some have argued, as for instance Stanley Fish, that there is no difference between ordinary and poetic language since formal and rhetorical devices are present in both $^{5}$. But, is it possible to maintain that phonic, syntactic, rhythmic, and even visual elements which in poetry are a constitutive part of the cognitive processes, play the same role in everyday language? The activity of translation represents an indirect proof of their differences. The loss of the original signification is much greater in translating a poetic text than an ordinary one. Furthermore, the translation of a highly experimental text can be essentially impossible; the result is often the creation of a different text which shares with the original a drastically reduced number of elements.

${ }^{5}$ See in particular the chapter titled "How Ordinary Is Ordinary Language", in Is There a Text in This Class? 
Undoubtedly, poetry is an epochal form inasmuch as it interacts with an intricate web of discourses, but it is not an exercise which transforms into its own language pre-constituted and ready-made messages derived from the work conducted in other fields and disciplines. Poetry engenders processes that build and create realities. It is the techne which, by stretching the verbal signs to their extreme limits, paves the way to expanding consciousness, cognition, and imagination. Indeed, it represents a particular cognitive process.

However, this raises a number of thorny questions. What is the relationship between the materiality of the poetic language and the subject? Is signification subjectless, the result of a disseminating play engendered by the signifiers, as maintained by deconstruction? The claim here is that poetry is not a monologic activity expressed either by a separate, autonomous subject, a predetermined entity of sensitivity and consciousness, or by an independent linguistic code. It is a dialogic process which is the result of an encounter between the desire of the subject, of a cognizing agent, and the intrinsic itineraries of meaning offered by language. The objective is not that of anchoring conquered states of consciousness to the written words, but to discover new openings of consciousness through writing as an alternative to that production of consciousness that we all engage into some degree or other by living our everyday lives. Subjectivity renews itself in the act of writing; it is a dynamic process. It is the effect of a dialectic, a dialectic between a subjectivity in motion and the flux of meanings inherent to language. Poetry, then, is a process of identification of the subject, the space where new modalities of subjectivity are formed. The poet is a nomad, a subject-in-process, constantly searching for new states of awareness through language.

Within this tradition, centered around the historical avantgardes (Italian and Russian Futurism, Dadaism, Surrealism) and the new avant-garde movements of the 1960s (in particular the Italian group I Novissimi and the French poets of Tel Quel), poetry becomes the locus of otherness, an anarchic linguistic construct which can resemble pathological language, the language of "madness". By forcing words to break with norms, poetry revolutionizes perceptions. Poetic praxis looks toward utopia. The explosion of the conventional historical forms negates present reality and projects the world toward the future. It is a transfiguration of the world. The vertiginous 
destabilization of meaning revitalizes the process of signification and favours alterity over the homogenization of subjectivity - rather alarming in today's mcdonaldization of culture promoted by transnational capitalism. Opposed to standardized and reified language, this poetry becomes an aesthetic attempt to reinstate art in the lifepraxis and provide cognitive modalities which can open up new social and political spaces. Formal experimentation engenders new modes of being-in-the-world.

The disorienting effects achieved by the poetic signifiers produce a definite and healthy distance from the habitual transparency of language. This sets in motion a process of unconscious displacement and condensation of signifiers that discloses the return of the repressed and liberates the subject from social and ideological constructs. The calculated "madness" of this poetic language represents a revolt against practices of social interdiction of discourses. By suspending the normality of dominant models of communication, this poetry enables the repressed and the marginalized to come to the surface - bodily and instinctual urges, otherness. Poetry opens up a human space not colonized by the hegemony of given social paradigms. The subject posits itself at an instinctual level, at a level of desire, that is at a level anterior to awareness and reflexive processes. Poetry allows desire to speak. In many ways it demonstrates Freud's penetrating maxim, "Where id was, there ego shall be" (Freud, 1964, p. 80).

This poetry is rooted in the effort to produce subjectivity through language. It is a source of cognition and desire. But like Plato's eros, cognition is a desire that can never achieve totality. But then, wouldn't totality transform humans into gods? Or into monsters?

York University

\section{References}

BAUDRILLARD, Jean (1981). Simulacres et simulation. Paris, Galilée.

DERRIDA, Jacques (1967). L'écriture et la différence. Paris, Seuil.

ECO, Umberto (1962). Opera aperta. Milan, Bompiani. 
FEYERABEND, Paul (1975). Against Method: An Outline of an Anarchist Theory of Knowledge. London, NLB.

FISH, Stanley (1980). Is There a Text in This Class? The Authority of Interpretive Communities. Cambridge (Mass.), Harvard University Press.

FOUCAULT, Michel (1969). L'archéologie du savoir. Paris, Gallimard.

FREUD, Sigmund (1964). The Complete Works of S. Freud. Vol. XXII. London, Hogarth Press.

KUHN, Thomas (1970). The Structure of Scientific Revolutions. Chicago, University of Chicago Press.

LEOPARDI, Giacomo (1983). Tutte le opere. Vol. II. Florence, Sansoni.

LYOTARD, Jean-François (1979). La condition postmoderne : rapport sur le savoir. Paris, Minuit.

NIETZSCHE, Friedrich (1974), The Gay Science. New York, Vintage Books.

POPPER, Karl (1959). The Logic of Scientific Discovery. London, Hutchinson.

RORTY, Richard (1980). Consequences of Pragmatism. Minneapolis, University of Minnesota Press.

VATTIMO, Gianni (1989). La società trasparente. Milan, Garzanti.

VICO, Giambattista (1968). The New Science (trans. of the 1744 edition by Th. G. Bergin and M. H. Fish). Ithaca, Cornell University Press.

ABSTRACT : Poetry, Science, and the Epistemological Debate The last few decades have witnessed a radical questioning of the cognitive possibilities traditionally associated both with science and 
literature. This article gives a brief overview of the debate and provides a critique of the deconstructive and post-modern theories in their attempt to subvert fundamental epistemological claims. The article then addresses the specificity of poetic cognition and, distancing itself from mimetic conceptions of poetry, proposes that poiesis entails a peculiar creation of reality, unattainable with other tools. It is the uniqueness of the materiality of poetic language that contributes to the formation of subjectivity and to the expansion of human reality and consciousness.

RÉSUMÉ : La poésie, la science et le débat épistémologique - Au cours des dernières décennies, nous avons assisté à une remise en question radicale des possibilités cognitives qui étaient traditionnellement associées à la littérature et à la science. Le présent article se veut un bref survol de ce débat et une critique de la déconstruction et du post-modernisme dans leur tentative de remettre en question certaines des revendications épistémologiques fondamentales. Par la suite, l'article aborde la spécificité de la cognition poétique et, se distinguant des conceptions imitatrices de la poésie, propose que la poiêsis entraîne une création particulière de la réalité, inaccessible avec d'autres outils. C'est le caractère unique de la matérialité du langage poétique qui contribue à la formation de la subjectivité et au développement de la réalité humaine et de la conscience.

John Picchione : York University, 4700 Keele Street, Toronto (Ontario) M3J 1P3.

Courriel : johnp@yorku.ca 